\title{
PELAKSANAAN TUGAS KEPOLISIAN DALAM MENGURANGI PENCURIAN DENGAN KEKERASAN DI WILAYAH POLRES PALOPO
}

\author{
Andi Takdir Djufri
}

Fakultas Hukum Universitas Andi Jemma Palopo

\begin{abstract}
Basically it is the responsibility of the police officers in tackling and preventing the occurrence of criminal acts, including the criminal act of theft with violence. However, there are obstacles in carrying out these functions and tasks. The constraints in question are if the perpetrators fled, lack of public awareness to be witnesses, still lack of facilities and infrastructure supporting the functions and duties of the police investigators and the lack of personnel of the police.
\end{abstract}

\section{Keywords:}

Theft, Violence, Police Officers, Palopo City

\begin{abstract}
Abstrak
Pada dasarnya merupakan tanggung jawab aparat kepolisisan dalam menanggulangi dan mencegah terjadinya tindak pidana, termasuk tindak pidana pencurian dengan kekerasan. Namun, terdapat kendala dalam menjalankan fungsi dan tugas tersebut. kendala yang dimaksud adalah jika pelaku melarikan diri, kurangnya kesadaran masyarakat untuk menjadi saksi, masih minimnya sarana dan prasarana pendukung fungsi dan tugas aparat penyidik kepolisian serta kurangnya personil aparat kepolisian.
\end{abstract}

Kata Kunci:

Pencurian, Kekerasan, Aparat Polisi, Kota Palopo

\section{A. PENDAHULUAN}

1. Latar Belakang

$\mathrm{B}$ anyaknya pencurian cenderung mengalami pergeseran kearah pencurian dengan menggunakan kekerasan fisik dan sering berakhir dengan kematian bagi si korban. Hal ini perlu disikapi secara serius oleh aparat kepolisian dalam mengurangi dan menanggulanginya agar dapat terhindar dari kejahatan yang berkepanjangan.

Dengan menekan laju tindak kejahatan termasuk pencurian dengan kekerasan dibutuhkan aturan hukum dan pelaksana hukum yang memadai dan tegas sebagaimana yang diatur dalam pasal 365 Kitab Undang-undang Hukum pidana 
tentang sanksi hukuman bagi pelaku dengan menggunakan cara kekerasan. Dalam melakukan penyelidikan tersebut, terdapat aparat kepolisian yang memiliki kewenangan untuk melakukan penyelidikan terhadap kasus-kasus kriminalitas yang melanda masyarakat sekarang ini.

Untuk itu, dengan keberadaan aparat kepolisian sangat dibutuhkan untuk mengantisipasi berbagai bentuk pencurian. Kondisi seperti itu sangat dimungkinkan tingkat kriminalitas termasuk kasus-kasus pencurian dengan kekerasan akan terjadi.

Sehingga dengan dimikian berdasarkan latar belakang tersebut, maka penulis tertarik untuk membahas serta melakukan penelitian tentang "Pelaksanaan tugas Kepolisian dalam mengurangi pencurian dengan kekerasan di Wilayah Hukum Polres Palopo".

\section{Rumusan Masalah}

Dari uraian latar belakang tersebut, maka dirumuskan masalah pokok yang menjadi bahasan dalam penelitian yakni:

1. Bagaimana kepolisian mencegah pencurian dengan bentuk kekerasan di Wilayah Hukum Polres Palopo?

2. Apakah kendala yang dihadapi dalam mengurangi pencurian dengan bentuk kekerasan di Wilayah Hukum Polres Palopo?

\section{Tujuan Penelitian}

Penelitian ini bertujuan untuk:

1. Untuk mengetahui bagaimana kepolisian menekan pencurian dengan bentuk kekerasan di Wilayah Hukum Polres Palopo.

2. Untuk mengetahui kendala dalam menekan pencurian dengan bentuk kekerasan di wilayah hukum Polres Palopo.

\section{Kegunaan Penelitian}

Penelitian ini berguna sebagai berikut:

1. Masukan bagi kepolisian dalam mengurangi pencurian dengan bentuk kekerasan di wilayah hukum Polres Palopo.

2. Menambah wawasan terhadap perkembangan ilmu hukum dan mengkaji masalah didalam masyarakat.

\section{B. TINJAUAN PUSTAKA}

\section{Delik Pencurian}

Poerwadarminta (1983:217) memberi makna kata "curi" dalam arti "berbagaibagai perkara pencurian". Setelah mendapat awalan pe dan akhiran an menjadi "pencurian" maka dimaknai sebagai "perkara (perbuatan dan sebagainya) mencuri". "curi" sama dengan maling, mencuri berarti mengambil secara sembunyi atau diamdiam barang milik orang lain tidak dengan jalan sah.

Tentunya apa yang terdapat dalam Kitab Undang-undang Hukum Pidana dikemukakan berbagai macam pengertian pencurian, yakni: 
(1) Pencurian biasa (pasal 362 KUHP)

Banyak macam dan bentuk pencurian dan yang diuraikan ialah pencurian biasa adalah perbuatan mengambil barang sesuatu yang seluruhnya atau sebagian milik orang lain dengan maksud untuk memiliki secara melawan hukum.

(2) Pencurian ringan (pasal $364 \mathrm{KUHP}$ )

Pencurian ringan adalah pencurian yang dilakukan tidak di dalam rumah dan harga curiga tersebut tidak lebih dari dua puluh lima rupiah.

(3) Pencurian berat (pasal $363 \mathrm{KUHP}$ )

Pencurian berat adalah pencurian yang dilakukan ketika keadaan bahaya kebakaran, letusan, banjir, gempa, gunung meletus, kapal karam, kapal terdampar, kecelakaan kereta api, huru hara, pemberontakan atau keadaan perang yang dikategorikan pula sebagai pencurian berat adalah pencurian yang dilakukan pada malam hari di rumah atau pekarangan tertutp yang ada rumahnya atau pencurian dengan merusak atau memotong atau memanjat atau menggunakan kunci palsu, perintah palsu, pakaian jabatan palsu.

(4) Pencurian dengan kekerasan (pasal $365 \mathrm{KUHP}$ )

Pencurian dengan kekerasan adalah pencurian yang dilakukan dengan kekerasan atau ancaman kekerasan atau dalam hal terungkap tangan.

(5) Pencurian dalam kalangan keluarga (pasal 367 KUHP)

Pencurian dalam kalangan keluarga adalah pencurian atau pembuat dalam salah satu jenis pencurian yang telah diatur, dilakukan oleh suami (isteri) yang tidak terpisah meja dan tempat tidur atau harta kekayaannya maka tidak dapat diadakan penuntutan kecuali jika mereka sudah terpisah meja atau tempat tidur dan harta kekayaannya, atau jika ia keluarga sedarah baik dalam garis lurus maupun garis menyimpang derajat dua, maka diadakan penuntutan jika ada pengaduan dari korban.

\section{Unsur- Unsur Pencurian}

Dari rumusan pasal 362 KUHP tersebut, R soesilo (1986:249) merumuskan unsur- unsur pencurian, yakni:

(a) Perbuatan mengambil

Unsur perbuatan mengambil harus dengan menguasai barang tersebut seolaholah sebagai miliknya sendiri dalam arti bahwa ia dapat berbuat bebas terhadap barang yang diambil itu.

(b) Yang diambil harus barang tanpa menentukan mempunyai nilai atau tidak.

Karena tindakan pencurian adalah tindakan yang merugikan kekayaan orang lain, maka barang yang diambil tersebut adalah barang yang berharga. Artinya, barang itu mungkin saja barang dengan nilai yang rendah tetapi sangat berharga bagi korbannya.

(c) Seluruhnya atau sebagian kepunyaan orang lain.

Misalnya, suatu warisan yang belum terbagi-bagi dan si pencuri adalah salah seorang ahli waris yang turut berhak atas barang warisan itu. 
(d) Tujuan memiliki dengan melawan hukum

Wujud memiliki dapat bermacam-macam seperti menjual, meminjamkan, memakai sendiri, mengandakan bahkan sering bersifat negatif yaitu tidak berbuat apa-apa dengan barang itu.

\section{Pengertian Tentang Delik}

Perkataan "delik" berasal dari bahasa Latin "delict" atau "delictum" yang ditransfer ke dalam bahasa Belanda menjadi strafbaarfeit (Lamintang 1990:172) strafbaar berarti dapat dihukum, dan feit berarti sebagian dari suatu kenyataan, sehingga secara harfiah strafbaar feit dapat diterjemahkan sebagai "sebagian dari suatu kenyataan yang dapat dihukum".

Penyelidikan sendiri didefinisikan Lamintang (1984:65) sebagai serangkaian tindak penyidik untuk mencari dan menemukan suatu yang diduga sebagai tindak pidana guna menentukan dapat atau tidaknya dilakukan penyelidikan menurut cara yang diatur dalam undang-undang.

Dalam ayat 13 pasal 1 Bab I UU Nomor 2 Tahun 2002 tentang Kepolisian Negara RI dikemukakan bahwa:

Penyidikan adalah serangkaian tindakan penyelidik dalam hal dan menurut cara yang diatur dalam undang-undang untuk mencari serta mengumpulkan bukti-bukti dengan bukti-bukti itu membuat terang tentang tindak pidana yang terjadi dan guna menemukan sangkanya.

Dari pengertian "penyidik" yang terdapat dalam undang-undang Nomor 2 Tahun 2002 tentang Kepolisian Negara RI, maka dapat dirumuskan dalam 4 (empat) hal pokok bahwa penyidik adalah:

a. pejabat Kepolisian Negara RI

b. Diberi wewenang dan tugas

c. Wewenang dan tugas tersebut diatur oleh undang-undang

d. Melakukan tugas penyelidikan

Dalam melakukan tugas dan wewenangnya, seorang penyidik sebelum melakukan penyilidikan terlebih dahulu harus memahami syarat-syarat penyeledikan sebagaimana diatur dalam pasal 16 ayat 2 UU Nomor 2 Tahun 2002, yaitu:

a. Tidak bertentangan dengan suatu aturan hukum

b. Selaras dengan kewajiban hukum yang mengharuskan tindakan tersebut dilakukan

c. Harus patut, masuk akal, dan masuk dalam lingkungan jabatannya

d. Pertimbangan yang layak dan berdasarkan keadaan yang memaksa, dan menghormati Hak Asasi Manusia

Kitab undang-undang Hukum Pidana (KUHP) juga memberikan dukungan tentang tugas dan peran penyidik untuk melakukan penyelidikan terhadap semua tindak pidana. Namun demikian, pelaksanaan penyelidikan harus tetap sesuai 
dengan perundang-undangan sebagai dasar hukumannya (penjelasan atas UU Nomor 2/2002).

Dalam undang-undang yang berlaku maupun dari berbagai literatur hukum memberikan istilah Straafbaarfeit adalah pengertian dari:

1. Peristiwa Pidana

Adalah suatu istilah dalam pencantuman Undang-undang Dasar sementara tahun 1950

2. Delik

Delictum berasal dari bahasa Latin, yang juga digunakan untuk menggambarkan tentang apa yang di maksud dengan strabaarfeit

Secara harfiah kata straf artinya pidana, baar artinya dapat atau boleh dan feit adalah perbuatan. Dalam kaitannya dengan istilah straafbaar feit secara utuh tenyata straf di terjemahkan juga dengan kata-kata hukum, pada hal sudah menjadi lazim hukum itu adalah berupa terjemahan dari kata recht seolah-olah straf sama dengan recht yang sebenarnya tidak bisa disamakan.

Sedangkan untuk kata peristiwa, menggambarkan pengertian yang lebih luas dari perkataan perbuatan, karena peristiwa itu tidak saja menunjuk pada perbuatan manusia, melainkan mencakup pada seluruh kejadian yang tidak saja di sebabkan oleh adanya perbuatan manusia, melainkan mencakup pada seluruh kejadian yang tidak saja disebabkan oleh adanya perbuatan manusia semata.

Moeljatno (1983:54) dengan menggunakan istilah "perbuatan pidana" sebagai perbuatan yang dilarang atau suatu aturan hukum larangan mana disertai ancaman (sanksi) yang berupa pidana tertentu bagi barang siapa melanggar larangan tersebut.

Selain itu, Rusli Efendi (1983:44) dengan istilah peristiwa pidana, memberikan pengertian peristiwa pidana sebagai suatu peristiwa yang dapat dikenakan pidana oleh hukum pidana.

Simons (Lamintang,1990:176) merumuskan strafbaar feit sebagai:

Tindakan melanggar hukum yang telah dilakukan dengan sengaja maupun tidak dengan sengaja oleh seseorang yang dapat dipertanggungjawabkan atas tindakannya dan oleh undang-undang telah dinyatakan sebagai suatu tindakan yang dapat dihukum.

Adapun unsur-unsur peristiwa pidana menurut aliran ini adalah:

a. Sesuai rumusan delik

b. Tidak ada lasan pembenar)

c. Ada kesalahan yang terjadi dari dolus dan culva.

Sedangkan aliran dualisme memisahkan antara unsur-unsur tersebut menjadi unsur perbuatan pidana dan unsur pembuat (Abidin Farid,1981:248) sebagai berikut: Unsur-unsur perbuatan meliputi:

- Sesuai dengan rumusan Delik

- Melawan Hukum

- Tidak ada alasan pembenar 
Unsur-unsur pembuat meliputi:

- adanya kesalahan

- Kemampuan bertanggung jawab

- Tidak ada alasan pemaaf

\section{Betuk Pencurian Biasa}

Dalam kehidupan sosial, istilah "kekerasan" diartikan dengan tindakan dengan menggunakan kekuatan fisik atau jasmaninya dalam memaksakan suatu hal misalnya memukul dan sebagainya.

1. Pengertian kejahatan menurut KUHPidana,

Secara spesik dalam kitab undang-undang Hukum Pidana (KUHP) tidak ditemukan, namun secara sistematika dalam pembagian buku II (buku kedua) Moeljono (KUHP, 1994: XVI) dan R. Soesilo (KUHP,1976:6), yaitu tentang kejahatan, disimpulkan bahwa semua pasal-pasal tentang perbuatan-perbuatan yang meliputi pasal 109-488 KUHP beserta perbuatan-perbuatan kejahatan lain di luar KUHPidana berupa undang-undang korupsi, terorisme, narkoba dsbnya.

2. Pengertian kejahatan menurut bahasa

Dalam kamus bahasa Indonesia, Poerwadarminta,1983:394), kata kejahatan berasal dari kata 'jahat yang berarti, sangat tidak baik; buruk; jelek' dan kata jahat ini diberi awalan ke dan ahiran an yaitu kejahatan yang berati,'sifat yang jahat; perbuatan yang jahat (seperti membunuh, menucuri dsbnya); dosa'.

Begitupun dalam kamus inggris, pengertian kejahatan (John. M. Echols dan Hasan Shadiliy (2000:154) diartikan sebagai "crime" berarti kejahatan dan pelakunya disebut "criminal" dan ilmu yang mempelajari tentang kejahatan disebut criminology.

Pencurian dengan kekerasan diatur dalam pasal 365 KUHP (Soesilo, 1988: 216) dengan rumusan sebagai berikut:

1. Dengan hukuman penjara selama Sembilan tahun, dihukum pencurian yang didahului, disertai atau diikuti dengan kekerasan atau ancaman kekerasan terhadap orang lain, dengan maksud akan menyiapkan atau memudahkan pencurian itu atau jika tertangkap tangan (kepergok) supaya ada kesempatan bagi dirinya sendiri atau bagi kawannya yang turut melakukan kejahatan itu akan melarikan diri atau supaya barang yang dicuri itu tetap ada ditangannya.

2. Hukum penjara selama 12 tahun dijatuhkan:

Ke-1 jika perbuatan itu dilakukan pada waktu didalam sebuah rumah atau pekarangan yang tertutup, yang ada rumahnya atau di jalan umum atau di dalam kereta api atau trem yang sedang berjalan.

Ke-2 jika perbuatan itu dilakukan oleh dua orang bersama-sama atau lebih.

Ke-3 jika sitersalah masuk ke tempat melakukan kejahatan atau dengan jalan membongkar atau memanjat atau dengan jalan memakai kunci palsu, perintah palsu atau pakaian jabatan palsu. 
Ke-4 jika perbuatan itu menjadikan ada orang mendapat luka berat

3. Hukuman penjara selama15 tahun dijatuhkan jika karena perbuatan itu ada orang mati.

4. Hukuman mati atau hukuman penjara seumur hidup atau penjara sementara selama-lamanya 20 tahun dijatuhkan, jika perbuatan itu menjadikan ada orang yang mendapat luka berta atau mati, dilakukan oleh dua orang atau bersamasama, dan disertai pula oleh salah satu hal yang diterangkan dalam nomor 1

\section{Bentuk Pencurian dengan Kekerasan}

Kriminal atau kriminologi secara etimologi berasal dari kata crime artinya kejahatan, sedangkan logi berasal dari kata logos yang artinya ilmu. Jadi kriminologi adalah pengetahuan mempelajari tentang seluk beluk kejahatan (B. Bosu,1992: 127).

Kriminologi lahir berawal dari pemikiran bahwa manusia merupakan srigala bagi manusia lain, selalu mementingkan diri sendiri dan tidak mementingkan keperluan orang lain maka diperlukan suatu norma untuk mengatur kehidupannya. (Topo santoso,2003:3)

Kriminologi sebagai suatu ilmu yang mempelajari gejala kejahatan seluasluasnya. Pengertian seluas-luasnya mengandung arti seluruh kejahatan dan hal-hal yang berhubungan dengan kejahatan. (Simanjuntak,1981:93).

Kriminologi adalah ilmu pengetahuan yang bertujuan menyelidiki gejala-gejala kejahatan seluas-luasnya. Sedangkan J. Constant mendefinisikan kriminologi sebagai ilmu pengetahuan yang bertujuan menentukan factor-faktor yang menjadi sebab musibab dari terjadinya kejahatan dan penjahat. (Bosu,1992:127)

WME Noach menyatakan bahwa kriminologi merupakan ilmu pengetahuan yang menyelidiki gejala-gejala kejahatan dan tingkah laku yang tidak senonoh, sebab musibab, serta akibat-akibatnya. (Bosu,1992:129)

Nama kriminologi ditemukan P. Topinard seorang ahli antropoli prancis, yang secara harfiah berasal dari kata "crime" yang berarti kejahatan atau penjahat dan logos berarti ilmu pengetahuan, maka kriminologi berarti ilmu tentang kejahatan atau penjahat. (Topo santoso,2003:9)

Boger memberikan defenisi kriminologi sebagai ilmu pengetahuan yang bertujuan menyelidiki gejala kejahatan seluas-luasnya, dimana kriminologi murni mencakup:

1. Antropologi kriminal, atau ilmu pengetahuan tentang manusia yang jahat (somatic). Ilmu pengetahuan ini memberikan jawaban atas pertanyaan tentang orang jahat sehubungan dengan tanda-tanda pada tubuhnya termasuk hubungannya dengan suku bangsa.

2. sosiologi criminal, adalah ilmu pengetahuan tentang kejahatan sebagai suatu gejala mesyarakat dengan penekanan pada letak sebab-sebab kejahatan dalam masyarakat.

3. psikologi criminal atau ilmu pengetahuan tentang penjahat dilihat dari sudut jiwanya. 
4. psikopatologi dan neuropatologi criminal yaitu ilmu tentang penjahat yang sakit jiwa atau urat syaraf

5. penology atau ilmu tentang tumbuh dan berkembangnya hukuman.

Kriminologi adalah ilmu pengetahuan yang bertujuan menyelidiki gejala-gejala kejahatan seluas-luasnya. sedangkan J. Constant mendefinisikan kriminologi sebagai ilmu pengetahuan yang bertujuan menentukan faktor-faktor yang menjadi sebab musibab dari terjadinya kejahatan dan penjahat. (Bosu,1992:127)

Diantara ahli kriminologi terdapat perbedaan tentang obyek studi kriminologi. ahli kriminologi tersebut terbagi dalam dua aliran yakni aliran hukum atau yuridis dan aliran sosiologis atau non yuridis (Topo santoso,2003:14). Pokok pandangan mereka adalah

1. Menurut aliran hukum atau yuridis, sasaran perhatian yang layak bagi kriminologi adalah yang diputuskan oleh pengadilan pidana sebagai penjahat oleh karena kejahatan yang dilakukannya. Dalam pengertian yuridis membatasi kejahatan sebagai perbuatan yang telah ditetapkan oleh negara sebagai kejahatan dalam hukum pidananya dan diancam dengan suatu sanksi. sementara penjahat merupakan para pelaku pelanggar hukum pidana yang diputus oleh pengadilan atas perbuatannya tersebut.

2. Aliran non Yuridis atau sosiologi berpendapat bahwa kejahatan merupakan suatu prilaku menuasia yang diciptakan oleh masyarakat. Walaupun masyarakat memiliki berbagai macam prilaku yang berbeda-beda, akan tetapi ada di dalamnya bagian-bagian tertentu yang memiliki pola yang sama. fenomena kejahatan pada dasarnya terjadi dalam suatu proses.

\section{METODE PENELITIAN}

\section{Lokasi Penelitian}

Penelitian ini di laksanakan diPolres Palopo dengan berbagai pertimbangan bahwa di wilayah tersebut banyak pencurian yang dilakukan secara kekerasan.

Populasi dalam penelitian ini adalah aparat Kepolisian Polres Palopo yang telah ditentukan yang memiliki kewenangan untuk memberikan data kepada penulis yang mengetahui peristiwa tersebut.

\section{Jenis dan Sumber Data}

Adapun jenis dan sumber data dalam penelitian ini terdiri atas:

a) Data Primer, yaitu data yang diperoleh dari hasil wawancara terhadap responden yang mengetahui kejadian di daerah tersebut.

b) Data Sekunder, yaitu data yang diperoleh melalui buku-buku, literatur lainnya.

\section{Teknik Pengumpulan Data}

Sebagai bahan memperoleh data yang berkaitan dengan masalah yang akan dibahas, maka digunakan tehnik pengumpulan data sebagai berikut: 
a. Penelitian Kepustakaan (library research) yaitu pengumpulan data dengan membaca dan mengkaji literatur yang berhubungan dengan masalah yang dibahas.

b. Penelitian Lapangan (field reseatch) yang dilakukan dengan terjun langsung kelokasi penelitian.

\section{Analisis Data}

Data yang diperoleh kemudian dianalisa secara kualitatif dan disajikan dalam bentuk deskriptif. berupa data pendukung untuk pembahasan dari masalah yang diteliti.

\section{PEMBAHASAN}

\section{Peran Kepolisian mengurangi Pencurian secara Kekerasan di Wilayah hukum Polres Palopo.}

Dalam kehidupan sehari-hari kita selalu menemukan masalah tentang pencurian bahkan bentuk pencurian bukan lagi hal yang baru, bahkan setiap saat selalu terdengar pencurian, bukan hanya dikota tetapi di pedesaan selalu terdengar dan termasuk klasifikasinya baik itu pencurian biasa maupun pencurian dengan kekerasan terutama yang sering terjadi di wilayah hukum Polres Palopo dimana merupakan kasus kriminal dengan jumlah yang cukup banyak baik pencurian ringan, pencurian berat, maupun pencurian dengan kekerasan kerap kali terjadi di wilayah Polres Palopo. Terjadinya pencurian banyak terjadi diwilayah hukum Polres Palopo karena di wilayah ini mempunya potensi terjadi karena di wilayah hukum Polres Palopo sebagai wilayah yang rawan akibat masyarakat di daerah tersebut hetrogen untuk berbagai kegiatan sehingga menyebabkan banyak kejadian yang dilakukan secara kekerasan.

Memperhatikan kondisi sosial ekonomi masyarakat yang cukup beragam, serta tingkat pendidikan yang tergolong rendah dimana tidak banyak menggunakan logika secara normal sehingga banyak kasus pencurian berat, maupun pencurian dengan kekerasan memiliki frekwensi peristiwa yang cukup banyak. Namun hal itu tidak dibayangkan karena wilayah hukum Polres Palopo dapat dikatakan daerah pinggiran yang mempunyai pandangan yang berbeda serta pendapatan yang masih sederhana.

Berbagai adanya perbandingan berbagai kasus kejahatan termasuk kejahatan pencurian dengan kekerasan yang ada pada berbagai wilayah hukum Polres Palopo termasuk kejahatan yang sering terjadi secara kekerasan sebagaimana dalam tabel dibawah ini.

Demikian juga delik pencurian dengan kekerasan yang terjadi di wilayah Hukum Polres Palopo dalam waktu tahun 2015 sampai dengan 2017 cenderung mengalami penurunan. hal tersebut dapat dicermati melalui tabel berikut: 
Tabel .1

Delik pencurian dengan kekerasan di wilayah Hukum Polres Palopo

\begin{tabular}{|c|c|c|}
\hline Tahun & Dilaporkan & selesai \\
\hline & & \\
2015 & 18 & 9 \\
2016 & 12 & 6 \\
\hline Jumlah & 9 & 20 \\
\hline
\end{tabular}

Sumber: Polres, 2018

Melihat table 1 tersebut menunjukkan bahwa kasus pencurian dengan kekerasan yang dilaporkan pada polisi Wilayah Hukum Polres Palopo periode tahun 2015 samapi dengan 2017 berjumlah 39 kasus. namun dari ke 39 kasus pencurian dengan kekerasan yang dilaporkan, dimana kasusnya dapat dieselesaikan sebayak 20 kasus.

Delik pencurian dengan kekerasan sebagaimana dijelaskan unsur-unsurnya sebagaimana yang tertuang dalam pasal 365, dilakukan oleh pelaku dengan latar belakang yang berada baik dari segi tingkat pendidikan, umur, maupun kondisi sosial ekonomi.

Penelitian tersebut semakin memperkuat bahwa kekuatan fisik seseorang berada pada kondisai puncak ketika berusia antara 21 sampai dengan 30 tahun, dan kondisi ini berpengaruh pada aktifitas atau kegiatan yang membutuhkan tenaga dan pemikiran yang kuat.

Demikian pula adanya berbagai peran penyidik dalam mencegah terjadinya delik dengan kekerasan diwilayah hukum Polres Palopo adalah dengan melakukan beberapa pendekatan antara lain:

\section{a. Tindakan Refresif}

Tindakan refresif dimana kebenaran dalam sebuah kasus pencurian dengan kekerasan, dibutuhkan penyelidikan yang hati-hati untuk menemukan unsur-unsur yang dipenuhi sehingga sebuah pencurian dapat dikategorikan kedalam pencurian dengan kekerasan.

Penyelidikan yang dilakukan oleh aparat penyidik mengarah pada pencarian dan pengumpulan bukti-bukti dimana bukti-bukti tersebut memperjelas tersangka dalam kasus tindak pidana termasuk pencurian dengan kekerasan.

Penyidik mempunyai peran yang besar dalam penegakan hukum dan sangat besar pengaruhnya, sebab dengan keberadaan penyidik salah satu unsur penentu dalam penetapan tersangka dapat diperoleh yakni bukti-bukti yang mengarah pada tindak pidana

Dari pendapat tersebut diatas, maka dapat ditarik kesimpulan berkaitan dengan tugas penyelidik yakni; pertama, tugas penyidik pada dasarnya mengarah 
pada pencarian bukti-bukti tindak pidana. kedua, bukti-bukti tersebut dijadikan dasar bagi penetapan tersangka.

Kepolisian mempunyai peran yang sangat besar dalam konsribusi yang diberikan aparat penyidik dalam menanggulangi pencurian dengan kekerasan khususnya di wilayah hukum Polres Palopo adalah melakukan penegakan ketentuan hukum sebagaimana yang telah ditentukan.

Untuk menanggulangi delik pencurian dengan kekerasan, penegakan hukum sangat dibutuhkan. Tentu saja, penegakan hukum ini harus berdasarkan analisis-analisis peristiwa di lapangan.

Keberadaan bukti-bukti disamping analisis peristiwa dalam kasus pencurian dengan kekerasan sangat dibutuhkan, sehingga penetapan tersangka dan penegakan hukum dapat dilakukan sesuai prosedur atau ketentuan yang telah ditetapkan.

Sebagai penyelidik wajib mengetahui ketentuan hukum sebelum melakukan penyidikan.hal tersebut dengan tegas telah diatur dalam pasal 16 ayat 2 undangundang Nomor 2 Tahun 2002 tentang Kepolisian Negara Republik Indonesia yang antara lain berbunyi bahwa seorang penyidik dalam menjalankan tugasnya tidak boleh bertentangan dengan suatu ketentuan hukum.

Dari hasil penelitian yang dilakukan dapat ditarik kesimpulan bahwa upaya penanggulangan atau menanggulangi delik pencurian dengan kekerasan oleh aparat penyelidik di wilayah hukum Polres Palopo yaitu dengan melakukan penegakan hukum berdasarkan hasil analisis peristiwa dan bukti tindak pidana kepada tersangka atau pelaku.

b. Tindakan Preventif

Disamping upaya menanggulangi terjadinya delik pencurian dengan kekerasan di wilayah hukum Polres Palopo melalui penegakan hukum berdasarkan analisis peristiwa dan bukti-bukti tindak pidana, aparat penyelidik juga melakukan berbagai upaya dalam rangka pencegahan atau tindakan preventif sehingga delik pencurian dengan kekerasan dapat terkikis dan tidak terjadi lagi.

Berbagai upaya termasuk dengan upaya preventif yang dilakukan aparat kepolisian wilayah hukum Polres Palopo khususnya aparat penyelidik terhadap delik pencurian dengan kekerasan adalah:

1. Penyuluhan Hukum.

Penyuluhan hukum ini adalah salah satu upaya preventif yang dilakukan adalah menggalakkan kepada masyarakat utamanya pada daerah atau lokasi yang telah ditetapkan sebagai daerah rawan dalam kasus pencurian.

Dengan adanya penyuluhan atau sosialisasi hukum pada dasarnya merupakan kewenangan dan tanggung jawab utama aparat kepolisian sebagaimana tertuang dalam pasal 15 undang-undang Nomor 2 Tahun 2002 tentang Kepolisian Negara Republik Indonesia. 
Berbagai tugas utama aparat kepolisian adalah mencegah dan menanggulangi berbagai bentuk pencurian di wilayah hukum Polres Palopo, dimana tugas ini sejalan dengan tugas pokok aparat kepolisian yang tertuang dalam pasal 13 undangundang Nomor 2 Tahun 2005 tentang Kepolisian Negara Republik Indonesia yakni memelihara keamanan dan ketertiban masyarakat.

Dalam menanggulangi penyakit masyarakat termasuk kasus pencurian dengan kekerasan, aparat penyidik beserta jajaran aparat kepolisian dalam wilayah hukum Polres Palopo mengajak masyarakat untuk lebih menggalakkan pengamanan swakarsa atau sistem Keamanan Lingkungan terutama di daerah yang rawan pencurian.

Dengan adanya bentuk penyuluhan yang diarahkan pada menumbuhkan kesadaran masyarakat bahwa kondisi dan situasi serta keamanan lingkungan bukan hanya tanggung jawab aparat penegak hukum atau aparat keamanan, tetapi juga tanggung jawab seluruh warga masyarakat.

Dengan adanya kesadaran hukum masyarakat sangat penting, sebab kondisi masyarakat sekarang sangat jauh berbeda dengan kondisi masyarakat dahulu. sikap gotong royong dan memprdulikan kesusahan tetangga sudah mulai bergeser ke gaya hidup saling tidak peduli. Akibatnya, sikap melindungi sudah semakin hilang.

Peran penyuluhan hukum bagi masyarakat sangat penting utamanya dalam merubah pola hidup masyarakat yang cenderung bergaya hidup mewah.hal tersebut perlu dicermati sebab umumnya korban pencurian dengan kekerasan adalah orangorang yang memiliki harta berlebih.

Kasus yang banyak dialami di wilayah hukum Polres Palopo selama ini cukup bervariasi. Demikian pula kasus pencurian dengan kekerasan yang dialami banyak korban yang dilakukan berbagai pelaku. Kehidupan mewah yang menyolok ditambah adanya kesempatan membuat tersangka leluasa untuk melakukan tindak pidana kejahatan pencurian dengan kekerasan.

Dari berbagai kasus menunjukkan bahwa usaha tindak pidana pencurian dengan kekerasan umumnya diarahkan pada orang-orang yang dianggap memiliki harta yang banyak, meskipun mungkin terdapat tindak pidana pencurian dengan kekerasan pada orang-orang dengan harta benda yang tidak seberapa besarnya.

2. Peningkatan Tugas Patroli

Upaya lain yaitu upaya preventif yang dilakukan aparat penyidik beserta jajaran aparat kepolisian Polres Palopo adalah meningkatkan tugas patroli.

Berkaitan dengan peningkatan tugas petroli ini, hal tersebut diungkapkan kanit Samapta mengemukakan bahwa:

Peningkatan tugas patroli sangat penting dalam rangka perhatian terhadap setiap peristiwa tindak pidana yang terjadi. dari beberapa kasus pencurian dengan kekerasan yang terjadi, umumnya peristiwa tersebut berlangsung ketika si korban dalam keadaan 
lengah atau kurang berhati-hati. Patroli dilakukan agar kesempatan atau ruang gerak pelaku di batasi.

Demikian juga usaha peningkatan tugas patroli akan memberikan dampak positif utamanya bagi masyarakat dalam rangka menumbuhkan kepercayaan masyarakat terhadap aparat keamanan.hal yang penting lainnya adalah memberikan scock terapy bagi pelaku pencurian dengan kekerasan dimana kesempatan untuk melakukan tindak pidana sangat terbatas bahkan tidak ada sama sekali.

\section{Kendala Aparat Dalam Menekan Pencurian secara Kekerasan di wilayah hukum Polres Palopo}

Tentunya dalam menekan berbagai kegiatan dan usaha yang dilaksanakan sebagai tugas kepolisian yang harus dilaksanakan, namun tentunya banyak hal yang menjadi hambatan dan tantangan dalam melaksanakan tugas-tugas terrsebut namun juga sudah ada faktor lain yang mendukung diadakannya penyelidikan antara lain:

1. Faktor Pendukung

Untuk menjalankan fungsi dan tujuan aparat penyelidik tidak terlepas dari faktor-faktor yang mendukung aktifitas tersebut. Faktor yang menjadi pendukung tugas aparat penyidik khususnya di wilayah hukum Polres Palopo adalah:

a. Pemberian Penghargaan

Upaya yang dilakukan yaitu pemberian penghargaan. pemberian penghargaan kepada aparat penyelidik yang dianggap berhasil dalam menjalankan tugasnya akan diberikan penghargaan baik berupa penilaian yang positif (kredit point) maupun dalam bentuk hadiah.

b. Meningkatkan Sumber Daya Manusia

Meningkatkan sumber daya manusia ini dialakukan untuk meningkatkan sumber daya manusia kepolisian dan juga diharapkan mendapat kesempatan untuk mengikuti pendidikan yang kejenjang yang lebih tinggi merupakan harapan seluruh aparat.hal ini sangat disadari sebab peningkatan pendidikan sangat berpengaruh pada peningkatan kualitas sumber daya sekaligus secara tidak langsung akan berhubungan dengan peningkatan jenjang karir kearah yang lebih tinggi.

2. Sedangkan Kendala yang dihadapi

Berbagai faktor pendukung, tugas dan tanggung jawab penyelidik khsusnya di wilayah Hukum Polres Palopo juga dipengaruhi oleh faktor kendala yang dihadapi. Adapun faktor penghambat antara lain:

a. Pelaku tidak ditemukan

Pelaku tindak pidana pencurian dengan kekerasan umumnya setelah melakukan tindak pidana tersebut melarikan diri sehingga tidak ditemukan. akibatnya penyidik hanya dapat melakukan penyelidikan dan tidak dapat secara langsung mengadakan penyidikan. 
b. Masyarakat tidak mau menjadi saksi

Realitas hukum dalam masyarakat kita adalah adanya ketakutan masyarakat untuk menjadi saksi. ketakutan ini dipicu oleh dua hal yakni ketakutan untuk dijadikan tersangka akibat kurangnya pemahaman tentang hukum dan ketakutan terhadap teman-teman pelaku tindak pidana untuk balas dendam. akibatnya, penyidik dalam melaksanakan tugasnya sangat sulit memperoleh informasi-informasi akurat khususnya yang berkaitan dengan pelaku tindak pidana tersebut.

c. Sarana dan prasarana yang terbatas

Sarana dan prasarana baik jumlah penyidik yang tidak berbanding dengan jumlah kasus maupun prasarana perkantoran dan kelengkapan lain turut mempengaruhi kondisi kerja aparat penyelidik. Ketersediaan perangkat kerja yang modern dengan jumlah yang memadai dianggap sangat membantu, utamanya dalam menyongsong penegakan hukum yang maksimal di masa akan datang.

d. Terbatasnya Personil

Terbatasnya personil merupakan salah satu faktor penghambat dari aktifitas penyelidik dalam menuntaskan berbagai macam kasus-kasus kriminal khususnya di wilayah Hukum Polres Palopo

e. Peningkatan sumber Daya Manusia

Peningkatan sumber daya manusia personil penyelidik dasarnya merupakan hal yang utama untuk saat ini. Dengan asumsi dasarnya adalah, meningkatnya jumlah kasus-kasus kriminalitas dengan tekhnik, cara, dan modus yang jauh lebih canggih dan modern merupakan tantangan tersendiri bagi aparat kepolisian termasuk aparat penyelidik.

\section{E. KESIMPULAN DAN SARAN}

\section{Kesimpulan}

Berbagai kesimpulan dalam penelitian ini yang kemudian menjadi titik tolak dari rumusan masalah yang telah ditetapkan, maka dapat disimpulkan sebagai berikut:

1. Pada dasarnya apa yang menjadi tanggungjawab aparat penyidik memiliki fungsi menanggulangi dan mencegah terjadinya tindak pidana termasuk tindak pidana pencurian dengan kekerasan.

2. Disamping itu, terdapat kendala dalam menjalankan fungsi dan tugas tersebut. kendala yang dimaksud adalah jika pelaku melarikan diri, kurangnya kesadaran masyarakat untuk menjadi saksi, masih minimnya sarana dan prasarana pendukung fungsi dan tugas aparat penyidik, kurangnya personil.

\section{Saran-Saran}

Disarankan untuk memberikan pemikiran bagi aparat penegak hukum serta masyarakat khususnya di wilayah Hukum Polres Palopo berkaitan dengan 
penanggulangan delik atau tindak pidana pencurian dengan kekerasan, maka perlu dikemukakan saran sebagai bahan pertimbangan bagi pihak dan masyarakat.

1. Perlu untuk meningkatkan penyuluhan hukum bagi masyarakat khususnya masyarakat yang berada di wilayah hukum Polres Palopo berkaitan dengan peningkatan peran serta masyarakat dalam menjaga keamanan dan ketertiban lingkungan secara swakarsa.

2. Perlunya peningkatan sarana dan prasarana penunjang dalam pelaksanaan fungsi dan tugas aparat penyidik baik dari penambahan personil kepolisian di wilayah hukum Polres Palopo

\section{Daftar Pustaka}

A. Ridwan, Halim, 1982, Hukum Pidana Dalam Tanya Jawab, Jakarta: Ghali Indonesia. Abidin Farid, A Z, 1987, Asas-asas Hukum Pidana, Bagian Jakarta: Cipta.

Ali, Ahmad, 1996, Menguak Tabir Hukum, Jakarta: Chandra Pratama.

Bawangen, Gersong W, 1982, Hukum Pidana dalam Teori dan praktek, Jakarta: Pradnya Paramita.

Erwin, Rudi T, 1991, Himpunan undang-undang dan peraturan Hukum Pidana, Jakarta: Aksara Baru.

Fahri, Ahmad, 1983, Ketentuan-ketentuan Pidana dalam Bidang Kearsipan dan Dokumentasi, Jakarta: Graha Jaya.

Hadikusuma. H Halim, 1992, Bahasa Hukum Pidana Indonesia, Bandung: Alumni.

Hamzah, A, 1991, Asas-asas Hukum Pidana, Jakarta: Rieneka Cipta.

Harahap, Yahya, 1988, Pembahasan, Permasalahan, dan Penerapan Acara Pidana, Jakarta: Pustaka Kartini.

Jhon, Echols dan Hasan shadily, 2000, Kamus Inggris Indonesia, Jakarta: Gramedia. Jonkers, JE, 1987, Buku Pedoman Hukum Pidana Hindia Belanda, Jakarta: Bina Aksara. Lamintang, PAF, 1984, Dasar-Dasar Hukum Pidana di Indonesia.

Soehartono, Irawan, 1995, Metode Penelitian Sosial, Rosdyakarya: Bandung. 